\title{
Collective violence and the culture of peace: researching the social psychology of memory and social reconciliation Introduction to the monograph
}

\author{
Violencia colectiva y cultura de paz: \\ investigación en psicología social de la memoria \\ y la reconciliación social \\ Introducción al monográfico \\ Nekane Basabe \\ University of the Basque Country (UPV/EHU) \\ Dario Páez \\ University of the Basque Country (UPV/EHU)
}

doi: http://dx.doi.org/10.18543/djhr.2282

Cómo citar/Citation: Basabe, Nekane; Páez, Dario. 2021. «Collective violence and the culture of peace: researching the social psychology of memory and social reconciliation. Introduction to the monograph». Deusto Journal of Human Rights, No. 8: 11-16. doi: http://dx.doi.org/10.18543/djhr.2282.

This monograph aims to disseminate the results of various research studies carried out in the field of social and community psychology. The studies focus on efforts to build a culture of peace in post-conflict contexts and societies that have suffered collective and socio-political violence, with multiple and persistent human rights violations.

The societies, groups and individuals affected by collective violence often mobilise resources as a means of coping with traumatic experiences. There are many different experiences of social reconciliation throughout the world that are based on recognition of the harm caused to victims and seek to guarantee inclusive memories and bring together different outlooks on conflict. These experiences lay the social and political groundwork for guaranteeing that the violence never happens again (López López \& Taylor 2021; Páez et al. 2011).

Since the end of the 20th century, many human rights defence mechanisms have been developed throughout Latin America and other continents undergoing transitions from dictatorial regimes to democracy. Two of the most commonly-used transitional justice 
mechanisms are truth commissions and trials. For example, following a long period of war and violence, Colombia is now waiting for the results of its truth commission. Processes of transitional justice often pursue instrumental goals such as restitution and compensation, while at the same time having an important symbolic effect, triggering intense emotional and moral reactions among participants and victims, as well as among society in general (Martín-Beristain et al. 2010).

In this sense, transitional justice can be viewed as a psychosocial process that seeks to ensure social reconciliation in societies which have been fragmented by collective violence and are now moving towards democracy. Social and intergroup reconciliation is therefore aimed at repairing relationships between different groups and rebuilding the social bonds that have been broken by violence. The objective is to eliminate psychological barriers in order to do away with stereotypes, decrease negative emotions and polarisation and break away from the logic of competitive victimisation in order to enable peaceful and harmonious coexistence through political procedures that do not use violence as a means of social control (Čehajić-Clancy et al. 2016; Gibson 2004).

At a collective level, international experiences of transitional justice range from the establishment of truth commissions and the recognition of the suffering caused, to diverse forms of reparation rituals. There are many different kinds of reparation rituals, including institutional apologies, public apologies by perpetrators, reparationoriented encounters between victims and perpetrators and the erection of monuments commemorating victims, to name but a few. All encompass human rights defence mechanisms and the recognition of the harm caused and are aimed at consolidating social norms that seek to avoid any repetition of the collective violence perpetrated, as well as to restore trust in institutions (Martin-Beristain et al. 2010).

At an individual level, victims need to learn to cope with the trauma they have experienced, in order to give their lives purpose once again and recover their trust in others, which has often been destroyed by the human violence perpetrated. Studies on the psychosocial effects of transitional justice rituals have found differences in their collective and individual impact on communities, institutions and individuals. Collective rituals in Rwanda involving perpetrators and victims were found to decrease negative stereotypes between groups in conflict, although they also had a negative emotional effect in terms of revictimisation, since victims were forced to relive their trauma (Rimé et al. 2011). Something similar was observed among indigenous communities in Guatemala (Martín-Beristain et al. 2010). Justice and 
reparation rituals have also been found to improve social climate and cohesion in the target group, and in this sense may help generate a sense of belonging to an imagined community, transforming the divisive representation of two groups in conflict into a more inclusive one. Nevertheless, collective and individual responses are not always consistent, and different victims may respond differently to memories, recollections or the idea of intergroup forgiveness.

Several countries in Latin America have suffered mass human rights violations by political dictatorships and/or terrorist attacks by military, paramilitary or guerrilla groups, and some (Argentina, Colombia, Brazil and Ecuador, among others) have implemented peace initiatives, such as Truth and Reparation Commissions (TRCs), with varying degrees of success and a range of different effects. This monograph presents a series of studies on the role and psychosocial impact of TRCs in these countries.

The first study focuses on Argentina, with the research team led by Elena Zubieta (University of Buenos Aires, CONICET) exploring the psychosocial impact of the transitional justice mechanisms (Truth Commission, National Commission on the Disappearance of Persons, criminal trials, institutional reforms and reparatory gestures) implemented to redress the harm caused by the military dictatorship (1976-1983). The study analyses the degree to which society approves of the mechanisms implemented, and measures emotional climate, trust in institutions, social sharing, willingness to forgive and willingness to engage in social reconciliation.

The next study analyses the situation in Colombia, a country which has suffered decades of armed conflict and war, with the resulting violence affecting both indigenous communities and urban areas, giving rise to polyvictimisation, with millions of victims and profound damage to the social fabric, all of which has served to undermine trust in social institutions. Following the peace agreement with the guerrilla group known as the FARC-EP, Colombia is now immersed in an intense social debate characterised by sharply opposing views. The article, which is the result of a collaboration agreement between the Pontifical Xaverian University of Bogota and the University of the Basque Country (Angélica Caicedo et $\mathrm{al}$.), analyses the social impact of the peace agreement and the role of the TRC through two complementary studies. The first engages in a textual analysis of media discourses during the establishment and consolidation of the peace agreement in 2016, and the second outlines the results of a quantitative analysis based on a survey about the working of the TRC in 2019-2020.

The next study was carried out by researchers from the University of Paraíba (Anderson Mathias et al.). Brazil suffered a military 
dictatorship from 1964 to 1985 . Twenty-seven years after the end of the regime, the National Truth Commission (NTC) was established in 2012, and concluded its work in 2014 with the issuing of a final report. The study presented here analyses social representations of Brazil's dictatorial past and the NTC, as part of the ongoing social conflict about the construction of a shared collective memory that also reflects current debates between different political stances. Consistently with Halbwachs' theory (1950/1968), which posits that memories reconstruct the past by adapting past events to the needs and group attitudes of the present, with collective memory being based on language communication during this process, the results of the study reveal how the ideological and political positions of the present influence the way in which social groups remember, forget or reinterpret the negative events of the past.

The next study focuses on the collective terrorist violence experienced in the Basque Country. Basque society suffered intense terrorist violence from 1960 to 2013. The study examines two community initiatives designed to foster the development of a culture of peace, the recognition of victims' suffering and intergroup forgiveness. The research was carried out by a team at the University of the Basque Country (Basabe et al.) and the researcher Miren Harizmendi from the Bakeola Foundation. The paper reports the results of two intervention studies. The first one, entitled Educational Programme with VictimEducators -Bakeaz blai, was quasi-experimental in nature, with a control group, and involved victims committed to the fight for memory and peace giving talks about their suffering and explaining why they are in favour of intergroup forgiveness. The intervention was unique in that it enabled direct contact with victims and their narratives of forgiveness. The intervention was found to encourage more favourable attitudes to social reconciliation. The second intervention, entitled Citizen Encounters, involved group discussions about memory and recognition between citizens from different municipalities. Both initiatives were unique in that they allowed victims to become educators and aimed to bring together people with very different views of the violent conflict.

The next study was led by Paula Tesche Roa from Andrés Bello University in Concepción, Chile, and focuses on the construction of a collective memory of the Chilean dictatorship (1973-1990) through cultural artefacts such as memorials and monuments built by the Chilean people to commemorate their violent past. As the authors state, these symbolic constructions link territory and memory as a means of configuring different forms of socio-political catastrophe. This 
study adopts a different perspective from the other works presented here, exploring the spatial, symbolic and functional dimensions of places dedicated to memory, using a qualitative methodology with diverse documentary sources.

Finally, the study by the research team from Ecuador, led by Carlos Reyes-Valenzuela and made up of researchers from various different universities (Andina Simón Bolívar, Politécnica Salesiana del Ecuador, and Playa Ancha, Chile), explores the influence of gender and its impact on the human rights violations outlined in the report issued by the Ecuadorian Truth Commission. In response to the severe human rights violations carried out by León Febres Cordero's government between 1984 and 1988, in May 2007, Rafael Correa's government established the Truth Commission of Ecuador (TCE), which concluded its work in 2010 after having gathered testimonies from 456 victims, most of whom had suffered various extreme forms of victimisation. A previous study had found high levels of posttraumatic stress (PTS) among the human rights violation victims featured in the TCE report. This study examines the role of gender in relation to the social impact of TRCs, an issue that has received very little attention to date, despite the fact that women are vulnerable to multiple extreme forms of victimisation and gender-based violence in situations of war and armed conflict.

This monograph presents a series of results regarding the effects of reparation rituals and TRCs, combining different methods and analysis strategies, including general population surveys, newspaper and social media content analysis, community intervention assessments and qualitative documentary analysis. In Argentina, the results revealed a medium-to-low level of knowledge regarding the transitional justice measures implemented, along with a generally positive attitude towards them. Official apologies were found to have a low level of effectiveness for improving intergroup trust. In Colombia, social representations of peace varied in accordance with the ideological stance adopted by the newspapers analysed, and the survey revealed that political stance and victimisation were crucial factors in the approval of the initiatives carried out by the Truth Commission and Special Jurisdiction for Peace. In Brazil, the comments analysed in three major newspaper websites reflected the public debate regarding memories of the dictatorship, with some narratives denying the existence of human rights violations. The results reveal that the struggle to maintain the collective memory is still ongoing today. The study carried out in the Basque Country highlighted the importance of victims playing an active role in memory and intergroup forgiveness rituals, through community 
initiatives targeted at the general population, which were evaluated systematically for the first time here. In Chile, the results reveal tension between remembering and forgetting, mainly between organisations that seek to establish the truth about what happened and rightwing groups that persist in denying the dictatorship. Finally, the study carried out in Ecuador found gender differences, with men expressing greater approval of the Truth Commission and reporting greater social inhibition of the emotions evoked by the violence suffered. The study also highlights the importance of gender roles for coping with a violent past.

\section{References}

Čehajić-Clancy, Sabina, Amit Goldenberg, James J. Gross, and Eran Halperin. 2016. Social-Psychological Interventions for Intergroup Reconciliation: An Emotion Regulation Perspective, Psychological Inquiry, 27, no 2: 73-88. https://doi.org/ 10.1080/1047840X.2016.1153945

Gibson, James L. 2004. Overcoming Apartheid: Can Truth Reconcile a Divided Nation? New York: Russell Sage Foundation.

Halbwachs, Maurice 1950/1968. La mémoire Collective. París: PUF.

López López Wilson and Laura K. Taylor, eds. 2021. Transitioning to Peace: Promoting Global Social Justice and Non-violence. Springer: Cham.

Martín-Beristain, Carlos, Dario Páez, Bernard Rimé, and Patric Kanyangara. 2010a. «Psychosocial effects of participation in rituals of transitional justice: A collective-level analysis and review of the literature of the effects of TRCs and trials on human rights violations in Latin America.» Journal of Social Psychology 25, no 1: 47-60. https://doi.org/10.1174/021347410790193450.

Páez, Darío, Carlos Martin-Beristain, José Luis González, Nekane Basabe, and Joseph de Rivera. 2011. Superando la Violencia Colectiva y Construyendo Cultura de Paz. Madrid: Fundamentos.

Rimé, Bernard, Patrick Kanyangara, Vincent Yzerbyt, and Dario Paez. 2011. "The impact of Gacaca Tribunals in Rwanda: Psychosocial effects of participation in a truth and reconciliation process after a genocide.» European Journal of Social Psychology 41, no. 6: 695-706. https://doi. org/10.1002/ejsp.822 


\section{Copyright}

Deusto Journal of Human Rights / Revista Deusto de Derechos Humanos is an Open Access journal; which means that it is free for full and immediate access, reading, search, download, distribution, and reuse in any medium only for non-commercial purposes and in accordance with any applicable copyright legislation, without prior permission from the copyright holder (University of Deusto) or the author; provided the original work and publication source are properly cited (Issue number, year, pages and DOI if applicable) and any changes to the original are clearly indicated. Any other use of its content in any medium or format, now known or developed in the future, requires prior written permission of the copyright holder.

\section{Derechos de autoría}

Deusto Journal of Human Rights / Revista Deusto de Derechos Humanos es una revista de Acceso Abierto; lo que significa que es de libre acceso en su integridad inmediatamente después de la publicación de cada número. Se permite su lectura, la búsqueda, descarga, distribución y reutilización en cualquier tipo de soporte sólo para fines no comerciales y según lo previsto por la ley; sin la previa autorización de la Editorial (Universidad de Deusto) o la persona autora, siempre que la obra original sea debidamente citada (número, año, páginas y DOI si procede) y cualquier cambio en el original esté claramente indicado. Cualquier otro uso de su contenido en cualquier medio o formato, ahora conocido o desarrollado en el futuro, requiere el permiso previo por escrito de la persona titular de los derechos de autoría. 